\title{
MICRONUTRIENTS AND BIOMASS IN Eucalyptus dunnii Maiden STAND'
}

\author{
Grasiele Dick ${ }^{2 *}$, Mauro Valdir Schumacher ${ }^{3}$, Dione Richer Momolli², Claudiney do Couto Guimarães ${ }^{4}$, \\ Huan Pablo de Souza ${ }^{2}$ and Aline Aparecida Ludvichak ${ }^{2}$
}

\footnotetext{
${ }^{1}$ Received on 31.01.2015 accepted for publication on 19.09.2016.

${ }^{2}$ Universidade Federal de Santa Maria, Programa de Pós-Graduação em Engenharia Florestal, Santa Maria, Rio Grande do Sul - Brasil. E-mail: <grasidick@hotmail.com>, <dionemomolli@gmail.com>, <huan.souza@storaenso.com>and $<$ aline_lud@yahoo.com.br>.

${ }^{3}$ Universidade Federal de Santa Maria, Departamento de Ciências Florestais, Santa Maria, RS - Brasil. E-mail: $<$ mvschumacher@gmail.com>.

${ }^{4}$ Stora Enso Florestal, Rosário do Sul, RS - Brasil.E-mail: <claudiney.guimaraes@Storaenso.com>.

*Corresponding author.
}

\begin{abstract}
The expansion of silviculture in Brazil, and the consequent intensive practices for soil preparation with high demand for fertilizers require sustainable nutrient management of forest sites. The objective of this study was to quantify the biomass and the micronutrient stocks of a 60-month-old Eucalyptus dunnii stand established in Alegrete, Rio Grande do Sul. The stand was established in a Rhodic Paleudult soil with low fertility and texture varying between sandy loam and sandy-clay loam. For the sampling of stand biomass, twelve trees were harvested, sectioned at ground level, and subsequently fractionated into the components roots, leaves, branches, stembark and stemwood to determine the dry mass and micronutrient content. The total biomass of the stand was $67.49 \mathrm{Mg} \mathrm{ha}^{-1}$, with mass allocation in descending order from: stem wood > root $>$ bark $>$ branches $>$ leaves. Total micronutrient stocks for boron (B), copper $(\mathrm{Cu})$, iron $(\mathrm{Fe})$, manganese $(\mathrm{Mn})$ and zinc $(\mathrm{Zn})$ were 562.57, 401.46, 9913.28, 31877.82, and $766.96 \mathrm{~g} \mathrm{ha}^{-1}$, respectively. In addition, we found greater accumulation of $\mathrm{Zn}$ in the wood, high $\mathrm{Mn}$ accumulation especially in the bark, and high Fe content in the roots. Therefore, based on these micronutrient levels and their allocation between biomass fractions, we emphasize that the practice of retaining forest residues on-site after harvest is essential for forest nutrition through nutrient cycling and for soil conservation and fertility.
\end{abstract}

Keywords: Forest nutrition; Nutrients cycling; Manganese

\section{MICRONUTRIENTES E BIOMASSA EM POVOAMENTO DE Eucalyptus dunnii Maiden}

RESUMO - A expansão da silvicultura no Brasil e as consequentes práticas intensivas para o preparo do solo, com elevada demanda por fertilizantes, requerem ações de manejo nutricional sustentável dos sítios florestais. O objetivo do presente trabalho foi quantificar a biomassa e o estoque de micronutrientes, em um povoamento de Eucalyptus dunnii, aos 60 meses de idade, estabelecido em Alegrete, Rio Grande do Sul. O povoamento foi implantado em solo do tipo Argissolo Vermelho Distrófico típico, com baixa fertilidade natural e textura variando entre franco-arenosa e franco-argilo-arenosa. Para a amostragem da biomassa, doze árvores foram abatidas e seccionadas ao nível do solo, onde posteriormente houve o fracionamento nos componentes: raízes, folhas, galhos, casca do tronco e madeira do tronco, com determinação de massa seca e teores de micronutrientes. Verificou-se que a biomassa total do povoamento foi de $67,49 \mathrm{Mg} \mathrm{ha}^{-1}$, com sequência decrescente de alocação de massa na ordem de: madeira do tronco $>$ raízes $>$ casca do tronco $>$ galhos > folhas. O estoque total de micronutrientes B, Cu, Fe, Mn e Zn na biomassa foi de 562,57; 401,46; $9.913,28 ; 31.877,82$ e 766,96 $\mathrm{g} \mathrm{ha}^{-1}$ respectivamente. Constatou-se maior acúmulo de zinco na madeira do tronco, elevado acúmulo de manganês especialmente na casca do tronco e de ferro nas raízes. Em função 
dos níveis de micronutrientes alocados na biomassa, enfatiza-se à prática de manutenção dos resíduos florestais no sítio após a colheita, indispensáveis para a nutriçãoflorestal, que através da ciclagem de nutrientes propiciam a conservação da fertilidade.

Palavras-chave: Nutrição Florestal; Ciclagem de nutrientes; Manganês.

\section{INTRODUCTION}

Forest stand establishment in Brazil, mainly that of eucalyptus species, has been occurring since the beginning of the last century, resulting in approximately 51 million hectares of total forests, of which seven million hectares are occupied with planted forest stands (ABRAF, 2013). Along with this promising scenario, there is a concern with sustainability, and the production must be achieved and avoiding to the maximum nutritional exhaustion of the site, also reducing fertilization expenditure.

To ensure rational use of mineral elements, Lopes and Abreu (2000) suggested that micronutrient fertilization in particular should be based not only on soil analyses, but also on vegetation responses and use efficiency of those nutrients. Micronutrients (i.e., trace minerals) are essential elements required in smaller amounts for the development of vegetation (Gupta, 2001). These, however, have recently been used commonly for fertilization in several regions and in diverse soil conditions, climates, and cultures of Brazil (Lopes and Abreu, 2000).

According to Abreu et al. (2007), the ability of plants to absorb and use micronutrients is reflected in their biomass nutritional balance. As such, knowledge of the dynamics of micronutrients in the soil is important for the management of fertilization practices and, in turn, the development of the vegetation. The aim of present study was to evaluate the micronutrient stocks of the above- and below-ground biomass of a Eucalyptus dunnii stand in the Pampa biome, Rio Grande do Sul state.

\section{MATERIALAND METHODS}

\subsection{Ecological characterization of the site}

This study was conducted in the Campaign region of Rio Grande do Sul state, approximately $76 \mathrm{~km}$ from Alegrete city, in the Sesmaria St. Ignatius Farm owned by the company StoraEnso Forest RS Ltd. The central geographical coordinates of the Eucalyptus dunnii stand are $29^{\circ} 47^{\prime}$ south and $55^{\circ} 17^{\prime}$ west, at an altitude of $98 \mathrm{~m}$. According to Matzenauer et al. (2011), the region is of a humid climate type, where the summers can show periods of drought, with average annual temperature and precipitation of $18.6^{\circ} \mathrm{C}$ and 1,574 $\mathrm{mm}$, respectively. The predominant vegetation in the region is the native fields characterized physiognomically by grasses interspersed by forest capons that occur along the rivers' courses (Boldrini et al., 2010).

Most of the soils of the Campaign region have basalt as their source material, but there are also areas covered by sandstone, with a large dominance of eutrophic Litolics or Regolithic Neosols, generally situated in smooth undulating relief (Streck et al., 2008). In the area where the stand was established, the soil was classified morphologically, and chemical and physical analyses were performed according to Tedesco et al. (1995). It was observed that the soil is of the type Rhodic Paleudult (Embrapa, 2006), with depth varying between intermediate and deep, with good drainage, and sandy texture varying from sandy loam to sandy loam as the depth increases.

According to the interpretation suggested by CQFS (2004), the soil of the experimental area has low organic matter content (SOM) and low $\mathrm{pH}$, low levels of calcium, magnesium, potassium, and phosphorus. In addition, the soil has an effective CTC average (t), and very low base saturation and high aluminum (Al) saturation. Boron (B), $\mathrm{Cu}$, and $\mathrm{Zn}$ contents (the latter for the 0$20 \mathrm{~cm}$ and $20-100 \mathrm{~cm}$ soil layers) are also shown in Table 1 .

This condition of low natural soil fertility, a typical soil situation in the Pampa Biome Campaign region, may be related to the predominance of the sand fraction in soil composition, its low organic matter content, and low availability of minerals such as calcium, magnesium, and potassium, which are indispensable for plant nutrition (Dechen and Nachtigall, 2007).

\subsection{Silvicultural practices of the stand}

The Eucalyptus dunnii stand establishment activities began in 2008, on an area that was under 
Table 1 - Chemical attributes (mean \pm standard deviation) of Rhodic Paleudult soil in the Eucalyptus dunnii stand. Tabela 1 - Atributos químicos (média \pm desvio padrão) do Argissolo Vermelho Distrófico típico em um povoamento de Eucalyptus dunnii.

\begin{tabular}{ccccccc}
\hline Attribute & Unit & \multicolumn{5}{c}{ Soil Layer $(\mathrm{cm})$} \\
\cline { 2 - 6 } & & $0-20$ & $20-40$ & $40-60$ & $60-80$ & $80-100$ \\
\hline $\mathrm{SOM}$ & $\%$ & $1,00 \pm 0,15$ & $0,91 \pm 0,10$ & $0,85 \pm 0,07$ & $0,78 \pm 0,07$ & $0,72 \pm 0,06$ \\
$\mathrm{pH}$ & $\left(1: 2,5 \mathrm{H}_{2} \mathrm{O}\right)$ & $4,74 \pm 0,06$ & $4,84 \pm 0,05$ & $4,96 \pm 0,03$ & $4,98 \pm 0,01$ & $5,00 \pm 0,07$ \\
$\mathrm{Al}^{3+}$ & $\mathrm{cmol}_{\mathrm{c}} \mathrm{dm}^{-3}$ & $1,99 \pm 0,14$ & $1,95 \pm 0,14$ & $1,91 \pm 0,32$ & $2,03 \pm 0,21$ & $1,75 \pm 0,25$ \\
$\mathrm{Ca}^{2+}$ & $\mathrm{cmol}_{\mathrm{c} \mathrm{dm}^{-3}}$ & $0,46 \pm 0,27$ & $0,79 \pm 0,17$ & $1,21 \pm 0,12$ & $1,84 \pm 0,44$ & $1,88 \pm 0,06$ \\
$\mathrm{Mg}^{2+}$ & $\mathrm{cmol}_{\mathrm{c}} \mathrm{dm}^{-3}$ & $0,33 \pm 0,10$ & $0,24 \pm 0,06$ & $0,27 \pm 0,02$ & $0,34 \pm 0,06$ & $0,40 \pm 0,01$ \\
$\mathrm{P}^{*}$ & $\mathrm{mg} \mathrm{dm}^{-3}$ & $1,87 \pm 0,09$ & $1,60 \pm 0,16$ & $1,49 \pm 0,09$ & $1,49 \pm 0,19$ & $1,54 \pm 0,19$ \\
$\mathrm{~K}^{*}$ & $\mathrm{mg} \mathrm{dm}^{-3}$ & $20,33 \pm 5,5$ & $12,00 \pm 3,6$ & $9,67 \pm 2,3$ & $8,33 \pm 1,53$ & $8,33 \pm 1,15$ \\
$\mathrm{t}$ & $\mathrm{cmol}_{\mathrm{c} \mathrm{dm}^{-3}}$ & $2,83 \pm 0,46$ & $3,01 \pm 0,38$ & $3,42 \pm 0,45$ & $4,22 \pm 0,66$ & $4,04 \pm 0,30$ \\
$\mathrm{~T}$ & $\mathrm{cmol}_{\mathrm{c}} \mathrm{dm}^{-3}$ & $8,96 \pm 1,36$ & $9,59 \pm 1,23$ & $10,11 \pm 2,0$ & $10,78 \pm 2,5$ & $10,95 \pm 1,7$ \\
$\mathrm{~V}$ & $\%$ & $9,07 \pm 3,11$ & $10,99 \pm 1,2$ & $15,15 \pm 1,8$ & $20,51 \pm 1,9$ & $21,22 \pm 2,5$ \\
$\mathrm{~m}$ & $\%$ & $71,30 \pm 9,8$ & $65,04 \pm 3,8$ & $55,73 \pm 2,0$ & $48,38 \pm 3,3$ & $43,17 \pm 2,8$ \\
$\mathrm{~B}$ & $\mathrm{mg} \mathrm{dm}^{-3}$ & $0,35 \pm 0,07$ & $0,42 \pm 0,12$ & $0,47 \pm 0,04$ & $0,43 \pm 0,07$ & $0,43 \pm 0,08$ \\
$\mathrm{Cu}$ & $\mathrm{mg} \mathrm{dm}$ & $2,29 \pm 0,40$ & $2,14 \pm 0,07$ & $2,20 \pm 0,21$ & $2,23 \pm 0,14$ & $2,01 \pm 0,21$ \\
$\mathrm{Zn}$ & $\mathrm{mg} \mathrm{dm}^{-3}$ & $0,57 \pm 0,09$ & $0,35 \pm 0,02$ & $0,24 \pm 0,01$ & $0,23 \pm 0,11$ & $0,29 \pm 0,17$ \\
\hline
\end{tabular}

Where: SOM is soil organic matter; $\mathrm{t}$ is CTC effective; $\mathrm{T}$ is $\mathrm{CTC} \mathrm{pH} 7 ; \mathrm{V}$ is Base Saturation; $\mathrm{m}$ is Saturation by aluminum. * Melich I method.

the process of soil degradation. Seedlings were planted from the seeds at a spacing of $2.0 \mathrm{~m} \times 3.5 \mathrm{~m}$ between plants.

In the area, soil preparation was performed with a subsoiler, mounted to a tire tractor, at an average depth of $60 \mathrm{~cm}$. Thereafter, phosphatization in line, irrigation, starter and cover fertilization, weeding in the line, and interlining were conducted here $300 \mathrm{~kg}$ $\mathrm{ha}^{-1}$ of formulation 06-30-06 of N- $\mathrm{P}_{2} \mathrm{O}_{5}-\mathrm{K}_{2} \mathrm{O}+0.6 \%$ of boron was applied. The second fertilizer addition was at 90 days after planting, where $140 \mathrm{~kg} \mathrm{ha}^{-1}$ of 22-0520 of $\mathrm{N}-\mathrm{P}_{2} \mathrm{O}_{5}-\mathrm{K}_{2} \mathrm{O}+0.2 \%$ of boron $+0.4 \%$ of zinc was applied. The third fertilization was at 270 days, using $140 \mathrm{~kg} \mathrm{ha}^{-1}$ of 22-00-18 of $\mathrm{N}-\mathrm{P}_{2} \mathrm{O}_{5}-\mathrm{K}_{2} \mathrm{O}+1.0 \%$ sulfur $+0.3 \%$ boron, applied mechanically in the interlinings.

\subsection{Quantification of stand biomass and micronutrient stocks}

At 60 months of age, in November 2012, samples of biomass above and below the soil were taken in four plots randomly distributed in the area, each with a dimension of $20 \mathrm{~m} \times 21 \mathrm{~m}$. The diameter at breast height $(\mathrm{DBH})$ and total height $(\mathrm{h})$ were measured from all trees in the plots to define four diametric classes, with three trees (lower, middle and upper limit), resulting in 12 repetitions.

The selected trees were accurately cubed according to the Smalian method (Péllico Netto and Brena, 1997), and subsequently fractionated into stemwood, stembark, branches, and leaves and heavy in its entirety, with hook balance of aid, and properly sampled and weighed on a precision scale (1.0 g). For stemwood and stembark, three sampling points distributed along the length of the commercial bole were determined, resulting in the wood fractions being divided into three equal parts. For minimum diameter of the bole (commercial diameter), the measure of eight centimeters was considered.

To estimate the micronutrient stocks, representative samples (150 g) of each biomass component were collected and weighed in the field with a precision scale. These were sent to the laboratory and dried in an air circulation oven at $70^{\circ} \mathrm{C}$ for $72 \mathrm{~h}$, after which the dry mass was determined using a precision digital scale $(0.01 \mathrm{~g})$ and modeling was applied to estimate the total amount of biomass per hectare.

The below-ground biomass was obtained from four trees, through the excavation of the soil using shovels, hoes, and backhoe, in $7.0 \mathrm{~m}^{2}$ area of the central limit tree in each of the tree diameter classes up to a depth of $1 \mathrm{~m}$. In this manner, the biomass produced per hectare was estimated based on the area of each plot.

The analysis of the micronutrients in the leaves and branches was performed by random sampling, considering thin, thick, live, and dead branches located throughout the crown. 
Samples of these biomass fractions were used to determine the concentrations of $\mathrm{B}, \mathrm{Cu}, \mathrm{Fe}, \mathrm{Mn}$, and $\mathrm{Zn}$, following the methodology of Tedesco et al. (1995). For the extraction of boron, dry digestion and analysis by spectrophotometry were used. For the other micronutrients, the perchloric nitrate $\left(\mathrm{HNO}_{3}+\mathrm{HClO}^{4}\right.$, 3:1) and the atomic absorption spectrophotometry methods were used. The amounts of micronutrients present in the compartments of Eucalyptus dunnii stand were calculated by means of the product of the average concentration of nutrients and the biomass.

\subsection{Statistical analyses}

For the statistical analysis of the micronutrient contents in the biomass components, the Tukey's test ( $\alpha=5 \%$ ) was performed using the software Assistat version 7.7 (SILVA; AZEVEDO, 2002), considering the completely randomized design with different number of repetition (i.e., twelve samples of each component of the biomass above the soil and four samples for the biomass below the soil were used). Modeling to estimate the biomass of the Eucalyptus dunnii stand was performed using the software SAS 13.0 for Windows (1996), considering a 5\% level of error probability using the stepwise procedure.

To estimate the stand biomass, the modeling used the equation st and $(y)=b_{0}+b_{1} x \ln ($ dap), which presented the best fit for all compartments $\left(\mathrm{R} \mathrm{aj}^{2}\right.$ greater than 0.90), where $\ln (y)$ represents the natural logarithm of the dry biomass ( $\mathrm{kg}$ per tree) of the components, In (dap) the natural logarithm of the diameter (DBH $\mathrm{cm})$ and $b_{0}$ and $b_{1}$ the regression coefficients.

\section{RESULTS}

\subsection{Eucalyptus dunnii biomass}

The results of the inventory showed that, at 60 months of age, trees of the Eucalyptus dunnii stand had a DBH of $12.0 \mathrm{~cm}$, h of $13.0 \mathrm{~m}$, basal area of $14.0 \mathrm{~m}^{2} \mathrm{ha}^{-1}$, a total density of 1,143 trees per hectare, and volume with bark of $124.3 \mathrm{~m}^{3} \mathrm{ha}^{-1}$. As such, the stand can be considered of low productivity, likely because of the its genetic composition, establishment of the seedlings from seeds, or the low soil fertility of the area.

The total biomass production in the Eucalyptus dunnii stand was $67.49 \mathrm{Mg} \mathrm{ha}^{-1}$, of which the biomass below the ground (i.e., root biomass) was $8.73 \mathrm{Mg} \mathrm{ha}^{-1}$ (13\%). For above-ground biomass, there was $3.55 \mathrm{Mg}$ $\mathrm{ha}^{-1}(5.3 \%)$ of leaves; $6.45 \mathrm{Mg} \mathrm{ha}^{-1}(9.5 \%)$ of branches; $7.94 \mathrm{Mg} \mathrm{ha}^{-1}$ (11.7\%) of stembark; and 40.82 $\mathrm{Mgha}^{-1}(60.5$ $\%)$ of stemwood.

\subsection{Nutrient stocks in tree components}

With respect to the micronutrient stocks in the stand, significant differences $(P \mathrm{~d}$ " 0.05$)$ in the concentrations of the elements were found among the different tree components (Table 2), with the micronutrients $\mathrm{B}$ and $\mathrm{Cu}$ being predominant in the leaves. The stemwood, which was the component with highest biomass allocation, showed low accumulation of all the measured elements.

It was observed that there was an expression of manganese, accumulated mainly in the stembark and leaves, which represent $11.7 \%$ and $5.3 \%$ of the total biomass of the Eucalyptus dunnii stand (Table 3), respectively. After $\mathrm{Mn}$, the mostpresent micronutrient was $\mathrm{Fe}$, which was concentrated mainly in the roots.

\section{DISCUSSION}

\subsection{Eucalyptus dunnii biomass}

The biomass allocation of Eucalyptus dunnii species followed the order of: stemwood $>$ roots $>$ branches

Table 2 - Concentrations of micronutrients in the different components of the biomass of Eucalyptus dunnii. Tabela 2 - Concentrações de micronutrientes nos diferentes componentes da biomassa de Eucalyptus dunnii.

\begin{tabular}{lccccc}
\hline Component & $\mathrm{B}$ & $\mathrm{Cu}$ & $\mathrm{Fe}$ & $\mathrm{Mn}$ \\
\cline { 2 - 6 } & \multicolumn{5}{c}{$\left(\mathrm{mg} \mathrm{kg}^{-1}\right)$} \\
\hline Leaves & $32,19 \mathrm{a}(28,0)$ & $8,59 \mathrm{a}(29,3)$ & $130,57 \mathrm{~b}(22,53)$ & $2.061,54 \mathrm{a}(33,74)$ & $12,57 \mathrm{a}(22,43)$ \\
Branches & $11,70 \mathrm{~b}(25,90)$ & $8,75 \mathrm{a}(24,23)$ & $42,44 \mathrm{c}(56,6)$ & $904,85 \mathrm{~b}(30,97)$ & $12,71 \mathrm{a}(24,97)$ \\
Stemwood & $2,21 \mathrm{c}(45,25)$ & $5,32 \mathrm{~b}(25,04)$ & $20,31 \mathrm{c}(58,93)$ & $142,85 \mathrm{~d}(18,67)$ & $10,36 \mathrm{~b}(39,68)$ \\
Stembark & $14,54 \mathrm{~b}(14,96)$ & $6,14 \mathrm{~b}(25,24)$ & $36,52 \mathrm{c}(26,27)$ & $1.321,89 \mathrm{~b}(29,37)$ & $14,23 \mathrm{a}(26,21)$ \\
Roots & $19,15 \mathrm{~b}(3,14)$ & $5,57 \mathrm{~b}(2,50)$ & $922,91 \mathrm{a}(4,92)$ & $274,47 \mathrm{c}(28,6)$ & $11,95 \mathrm{a}(17,93)$ \\
\hline
\end{tabular}

The averages followed by the same letter in the column within each component do not differ by the Tukey test at $5 \%$ probability. Value in parentheses $=$ coefficient of variation between replicates. 
Table 3 - Amount of micronutrients in the different components of the biomass of Eucalyptus dunnii. Tabela 3 - Quantidades de micronutrientes nos diferentes componentes da biomassa do povoamento de Eucalyptus dunnii.

\begin{tabular}{lccccc}
\hline Component & $\mathrm{B}$ & $\mathrm{Cu}$ & $\mathrm{Fe}$ & $\mathrm{Mn}$ & $\mathrm{Zn}$ \\
\cline { 2 - 6 } & \multicolumn{5}{c}{$\left(\mathrm{g} \mathrm{ha}^{-1}\right)$} \\
\hline Leaves & 114,27 & 30,49 & 463,52 & $7.318,47$ & 44,62 \\
Branches & 75,46 & 56,44 & 273,74 & $5.836,28$ & 81,98 \\
Stemwood & 90,21 & 217,16 & 829,05 & $5.831,14$ & 423,06 \\
Stembark & 115,45 & 48,75 & 289,97 & $10.495,81$ & 112,98 \\
Roots & 167,18 & 48,62 & $8.057,0$ & $2.396,12$ & 104,32 \\
\hline Total & 562,57 & 401,46 & $9.913,28$ & $31.877,82$ & 766,96 \\
\hline
\end{tabular}

$>$ barkwood $>$ leaves. More than $70 \%$ of the stand biomass was above-ground, and the highest proportion of total biomass corresponded to the stemwood. Therefore, for appropriate nutritional management of this soil, it is recommended that only the stemwood be removed from the site during forest harvest, leaving the residues such as leaves, branches, stembark, and roots on-site. Nevertheless, the stemwood also had low concentrations of micronutrient elements (discussed in section 4.2).

As for the below-ground biomass, roots represented a considerable part of the total biomass, which was within the expected range. For example, according to Foelkel (2014), the roots can constitute $10 \%$ to $25 \%$ of the total mass of forest biomass, depending on the species of eucalyptus and the quality of the stands. The age of the stand can also be a determining factor for the amount of root biomass. Indeed, Schumacher et al. (2011) in a study with the genus Eucalyptus verified that there is a trend of root increase with increasing age. The authors found 5.61 and $25.17 \mathrm{Mg} \mathrm{ha}^{-1}$ of root biomass at 4 years and 8 years of age, respectively.

In this study, we found $58.76 \mathrm{Mg} \mathrm{ha}^{-1}$ of biomass above the soil. Biomass production in a forest stand may also be linked to the soil type of the site. Hernández et al. (2009) in a study with Eucalyptus dunnii at age 9, but established in a soil with high organic matter content, in Algorta, Uruguay, recorded a high biomass production of $236 \mathrm{Mg} \mathrm{ha}^{-1}$. The authors found that the highest biomass proportion was allocated to the stemwood (172 $\mathrm{Mg} \mathrm{ha}^{-1}$ ), followed by stembark (29 $\mathrm{Mg} \mathrm{ha}^{-1}$ ), branches $\left(22 \mathrm{Mg} \mathrm{ha}^{-1}\right)$, and leaves $\left(13 \mathrm{Mg} \mathrm{ha}^{-1}\right)$. In another study in a low fertility site, Gatto et al. (2014) estimated the biomass of a 5-year-old Eucalyptus urophylla $x$ Eucalyptus grandis stand and found results similar to the present study, with $57.36 \mathrm{Mg} \mathrm{ha}^{-1}$ of stemwood, $8.08 \mathrm{Mg} \mathrm{ha}^{-1}$ of branches, $5.03 \mathrm{Mg} \mathrm{ha}^{-1}$ of barkwood, totaling $69.19 \%$ of the total biomass in addition to $4.02 \mathrm{Mg} \mathrm{ha}^{-1}$ of leaves.

\subsection{Nutrient stock in biomass}

This study found that there was no deficiency in the nutrient stocks in the biomass, considering the nutritional status of the leaves reported by Alfaia and Uguen (2013). In the stemwood, which was the component with the highest biomass allocation, there was less accumulation of the measured nutrient elements, with the exception of zinc, which suggests little removal of micronutrients from the site due to forest harvesting.

It was also observed micronutrient storage in the biomass compartments followed the descending order of: $\mathrm{Mn}>\mathrm{Fe}>\mathrm{B}>\mathrm{Zn}>\mathrm{Cu}$. This result corroborated Viera et al. (2013) who found similar magnitude of concentrations of micronutrients, except boron, in Eucalyptus urophylla $x$ Eucalyptus globulus stand. Another study by Guimarães (2014) also found the concentrations of micronutrients of a Eucalyptus dunnii stand in the order of $\mathrm{Fe}>\mathrm{Mn}>\mathrm{B}>\mathrm{Zn}>\mathrm{Cu}$.

The high concentrations of manganese in all components of the trees indicate the eucalyptus propensity to accumulate this micronutrient. This tendency was also observed by Viera et al. (2013) and Guimarães (2014). On the other hand, manganese is an essential nutrient to the plant, considering that it directly contributes to the process of photosynthesis, forms part of complex of water molecules, and is used in the conversion of light to energy which consequently releases oxygen into the atmosphere (Taiz and Zeiger, 2013). The high accumulation of $\mathrm{Mn}$ in the biomass can be explained by the low mobility of this micronutrient (i.e., an element of insufficient redistribution), since the transportation is done unidirectionally through the xylem and after accumulation in the leaves it is not re-mobilized or can be removed by washing (Malavolta et al., 1997; Prado, 2008). 
The most important micronutrient is Fe, mainly in the roots, a phenomenon that occurs due to the adsorption of oxide particles on the root surface, which is difficult to remove in the sampling process. However, significant amounts of stemwood indicate the low mobility of this nutrient (Malavolta et al., 1997).

Quantification of micronutrients contained in the biomass is essential for the nutritional management of forest stands, ensuring the rational use of chemical fertilizers. Based on the nutritional status of the Eucalyptus dunnii stand observed in the present study, precautions regarding manganese dosages in future fertilization practices are required, since the absence of this micronutrient drastically reduces the productivity of the stand (Marenco and Lopes, 2009). Moreover, according to Leite et al. (2014), high concentration may favor the onset of diseases such as drought of pointers.

\section{CONCLUSION}

We found low quantities of micronutrients in the stemwood of a Eucalyptus dunnii stand, which is generally removed from the forest site at harvest. We recommend that attention be paid to the maintenance of the forest residues on-site, such as leaves, branches, and stembark, which will be crucial for forest nutrition through the cycling of nutrients, improving soil conservation and fertility for the implantation of future stands of Eucalyptus dunnii in the area.

\section{ACKNOWLEDGMENTS}

The authors thank StoraEnso for the financial support and availability of the experimental area.

\section{REFERENCES}

Associação Brasileira de Produtores de Florestas Plantadas - ABRAF. Anuário estatístico da ABRAF: Ano base 2012. Brasília: 2013. 146p.

Abreu CA, Lopes AS, Santos GCG.

Micronutrientes. In: Novais RF, Alvarez V VH, Barros NF, Fontes RLF, Canarutti RB, Neves JCL, editores. Fertilidade do solo. Viçosa, MG: Sociedade Brasileira de Ciência do Solo; 2007. p.275-374.

Alfaia SS, Uguen K. Fertilidade e manejo do solo. In: Moreira FMS, Cares JE, Zanetti R, Stürmer SL.
O ecossistema solo: componentes, relações ecológicas e efeitos na produção vegetal. Lavras: Universidade Federal de Lavras; 2013. 352p.

Boldrini II, Ferreira PMA, Andrade BO, Schneider AA, Setubal RB, Trevisan R. et al. Bioma Pampa: diversidade florística e fisionômica. Porto Alegre: Pallotti; 2010. 64p.

Comissão de Química e Fertilidade do Solo CQFS. Manual de adubação e de calagem para os Estados do Rio Grande do Sul e de Santa Catarina. 10 ${ }^{\mathrm{a}}$.ed. Porto Alegre: SBCS: 2004. 400p.

Dechen AR, Nachtigall GR. Elementos requeridos à nutrição de plantas. In: Novais RF, Alvarez V VH, Barros NF, Fontes RLF, Canarutti RB, Neves JCL, editores. Fertilidade do solo. Viçosa, MG: Sociedade Brasileira de Ciência do Solo; 2007. p.91-132.

Empresa Brasileira de Pesquisa Agropecuária Embrapa. Sistema brasileiro de classificação de solos. $2^{\mathrm{a}}$ ed. Rio de Janeiro: Embrapa Solos; 2006. $306 \mathrm{p}$.

Foelkel C. Minerais e nutrientes das árvores dos eucaliptos: Aspectos ambientais, fisiológicos, silviculturais e industriais acerca dos elementos inorgânicos presentes nas árvores. Eucalyptus Online Book \& Newsletter. 2014.

Gatto A, Bussinger AP, Ribeiro FC, Azevedo GB, Bueno MC, Monteiro MM. et al. Ciclagem e balanço de nutrientes no sistema solo-planta em um plantio de Eucalyptus sp. no Distrito Federal. Revista Brasileira de Ciência do Solo. 2014;38(3):879-87.

Guimarães CC. Biomassa e nutrientes em plantios de eucaliptos no bioma Pampa [dissertação]. Santa Maria: Universidade Federal de Santa Maria; 2014. 63p.

Gupta UC. Micronutrientes e elementos tóxicos em plantas e animais. In: Fereira ME, Cruz MCP, Raij B van, Abreu CA, editores. Micronutrientes e elementos tóxicos na agricultura. Jaboticabal: Potafos; 2001. 600p.

Hernández J, Del Pino A, Salvo L, Arrarte G. Nutrient export and harvest residue decomposition patterns of a Eucalyptus 
dunnii Maiden plantation in temperate climate of Uruguay. Forest Ecology of Management. 2009;258(2):92-9.

Leite FP, Novais RF, Silva IR, Barros NF, Neves JCN, Medeiros AGB, et al. Manganese accumulation and its relation to "eucalyptus shoot blight in the Vale do Rio Doce". Revista Brasileira de Ciência do Solo. 2014;38(1):193-204.

Lopes AS, Abreu CA. Micronutrientes na agricultura brasileira: evolução histórica e futura. Tópicos em Ciência do Solo. Viçosa, MG, Sociedade Brasileira em Ciência do Solo, 2000;1:265-98.

Malavolta E, Vitti GC, Oliveira SA. Avaliação do estado nutricional das plantas: princípios e aplicações. $2^{\mathrm{a}}$.ed. Piracicaba: Associação Brasileira para a Pesquisa do Potássio e do Fosfato; 1997. 319p.

Marenco RA, Lopes NF. Fisiologia vegetal: fotossíntese, respiração, relações hídricas e nutrição mineral. $3^{\mathrm{a}}$.ed. Viçosa, MG: Universidade Federal de Viçosa; 2009. 486p.

Matzenauer R, Radin B, Almeida IR, editores. Atlas Climático: Rio Grande do Sul. Porto Alegre: Secretaria da Agricultura Pecuária e Agronegócio; Fundação Estadual de Pesquisa Agropecuária (FEPAGRO); 2011.

Péllico Netto S, Brena DA. Inventário florestal. Santa Maria: FSM/CEPEF/FATEC; 1997. 315p.
Prado RM. Nutrição de plantas. São Paulo: Universidade Estadual de São Paulo; 2008. 407p.

Schumacher MV, Witschoreck R, Calil FN. Biomassa em povoamentos de Eucalyptus spp. de pequenas propriedades rurais em Vera Cruz, RS. Ciência Florestal. 2011;21(1):17-22.

Silva FS, Azevedo CAV. Versão do programa computacional ASSISTAT para o sistema operacional Windows. Revista Brasileira de Produção Agroindústrial. 2002;4(1):71-8.

Streck EV, Kämpf N, Dalmolin RSD, Klamt E, Nascimento PC, Schneider P, et al. Solos do Rio Grande do Sul. $2^{\mathrm{a}}$.ed. Porto Alegre: EMATER/RSASCAR; 2008. 222p.

Taiz L, Zeiger E. Fisiologia vegetal. $5^{\text {a }}$.ed. Porto Alegre: Artmed; 2013.918p.

Tedesco MJ, Ginello C, Bissani CA, Bohnen H, Volkweiss SJ. Análise de solo, plantas e outros materiais. $2^{\mathrm{a}}$.ed. Porto Alegre: Universidade Federal do Rio Grande do Sul; 1995. 174p.

Statistical Analysis System - SAS. Sistema integrado de aplicações para análise estatística de dados. Cary: 1996.

Viera M, Schumacher MV, Truby P, Araujo EF. Biomassa e nutrientes em um povoamento de Eucalyptus urophylla x Eucalyptus globulus, em Eldorado do Sul-RS. Enflo. 2013;1(1):1-13. 